\title{
FRIENDLY ENVIRONMENTAL POLICIES IMPLEMENTATION WITHIN THE COMPANY: AN ESG RATINGS ANALYSIS AND ITS APPLICABILITY TO COMPANIES' ENVIRONMENTAL PERFORMANCE ENHANCEMENT
}

\author{
SEGARRA-OÑA M. ${ }^{1, *}$ \\ PEIRÓ-SIGNES A. ${ }^{1}$ \\ MONDÉJAR-JIMÉNEZ J. ${ }^{2}$ \\ SÁEZ-MARTÍNEZ F.J. ${ }^{3}$
}

\author{
${ }^{1}$ Management Department, 7D building, Camino de Vera, $s / n$, \\ Universitat Politècnica de València, Spain \\ ${ }^{2}$ Edificio Cardenal Gil de Albornoz, Avda. de los Alfares, 44, 16.071 \\ Social Sciences School \\ University of Castilla-La Mancha, Cuenca, Spain \\ ${ }^{3}$ Energy and Environment Science and Technology \\ Campus of International Excellence \\ Ed. Jurídico - Empresarial "Melchor de Macanaz" \\ Plaza de la Universidad, 102071 Albacete, Spain
}

Received: $11 / 11 / 2014$

Accepted: 25/11/2016

Available online: 02/12/2016 *to whom all correspondence should be addressed: e-mail: maseo@omp.upv.es

\begin{abstract}
In order to move towards a more environmentally oriented economy, society needs to be aware and able to recognize environmental friendly practices. Firms are increasingly relying on environmental scores ratings to make strategic decisions. In this context, understanding how day-to-day company's decisions affect environment scores is crucial. This paper examines the impact of social policies on the environmental scores of companies. Using data on for 3895 firms from the ASSET4 database between 2006 and 2010, we report on how employment quality, health and safety, training and development and diversity policies affect firms' environmental scores. An ANOVA test, followed by a regression analysis, was ran to test differences between the major markets. Also, the interaction between the selected variables and environmental scores, was tested in order to investigate the individual effects of social policies and location on environmental performance. Results show that environmental scores increase with the presence of social policies, and that the location of the company is a differentiating factor. The paper concludes with a discussion of the implications of these findings for future environmental promotion within companies.
\end{abstract}

Keywords: ESG ratings, environmental scores, social policies, environmental policies, firm performance

\section{Introduction and objectives statement}

There is increased importance placed on environmental, social, and corporate governance (ESG) ratings (Kemp et al., 2005; Kolk and Pinkse, 2010; Alonso-Almeida et al., 2014). However, the ESG concept is multi-dimensional, which makes it more difficult to reach clear conclusions. That is why understanding how company's decisions affect environment scores is crucial as it influences strategic decisions (Cheng et al., 2014; Sugita and Takahashi, 2015).

Previous studies have focused on determining the relationship between ESG scores and economic performance (Hong and Kacperczyk, 2009, for example). Although most companies' policies aim to increase economic results and competitiveness (Garau et al., 2011; Dobler et al., 2012), an effective 
environmental strategy has been denoted to be a key element of competitive advantage (Porter and Van der Linde, 1995a; 1995b; Griffiths, 2004). Therefore, environmental scores have become a key performance indicator of the level of environmental engagement and generate valuable information on the potential competitive advantages of a company (loannou and Serafeim, 2010).

According to Franck (2002), environmental research development should rely on daily basis analysis and recommendations.

This study is based on Thomson Reuters ASSET4's integrated ratings for the period 2006-2010. Data was gathered on more than 3000 global companies to evaluate how female presence in the companies and their respective diversity policies (which try to promote a work-life balance) affect companies' environmental performance, as measured by the environmental scores. Furthermore, we analysed differences across major markets in Europe, North America and the rest of the world, the latter being mainly composed of Asian companies.

However, although many benefits of an environmental approach have been detected and society is asking for a change from different positions (Hall and Vredenburg, 2004; Charisiou and Goula, 2014), there are still many barriers to improve companies' environmental performance (Sullivan, 2002) such as organizational culture and change management (Eiadat et al., 2008; Eccles et al., 2012). In order to change what employees are committed to or care about, it is important to make cultural changes that target the environmental performance of the company (Perron et al., 2006): we cannot expect higher commitment from employees, especially women, if other basic social needs are not fully covered. Therefore, developing diversity policies, such as flexible working hours (FWH) or day-care services (DCS), should increase the environmental awareness of employees. We believe that as basic social needs are covered, they will be more motivated to commit to a more environmental approach, in the line that also indicates Meissner (2015). The role of women, following the feminist theory (Humm, 1995) and its beliefs of women understanding and improving the relationship between places and people (Schneekloth, 1994; Merchant, 1981 ) is key in linking social and environmental awareness. Furthermore, in recent studies we found that the percentage of women employees decreases environmental scores while the percentage of women managers does not have a significant impact (Segarra-Oña et al., 2014). Based on this, we state our first hypothesis:

\section{H1: Companies' environmental scores are affected by social policies implementation.}

The differences between the location of companies in the developed markets and their environmental scores have been already analyzed, finding that environmental scores increase with the presence of diversity policies and the location of the company outside Asia (Peiró-Signes et al., 2012). As such, we can also expect to see different social commitments and the effects of social policies across major markets basically due to the big differences regarding the coverage of women's basic needs (Dankelman and Davidson, 2013; Stromquist, 2014). Thus, we set our second hypothesis as follows:

H2: The influence on the environmental score of companies varies depending on where companies are located.

\section{Methods}

The data for this study was retrieved form Thomson Reuters ASSET4 database, which is a leading provider of ESG data (Collison 2008; Filbeck, 2009). We extracted integrated ratings and key performance indicators (KPI) for 3895 firms with available ESG scores for the period 2006-2010. Although data is available from 2002, we dismissed data from 2002 to 2005 because of its scarcity.

This study is focused on ASSET4 qualitative data related to social policies, such as employment quality, health and safety, training and development and diversity, for companies worldwide (see Table 1).

These KPIs measure a company's management commitment and effectiveness towards providing highquality employment benefits and job conditions, a healthy and safe workplace, training and development, 
and equal opportunities in its workforce (Kolk and Pinkse, 2010; Mio and Venturelli, 2012). Therefore, they reflect a company's capacity to increase its workforce loyalty and productivity by distributing rewarding and fair employment benefits; by focusing on long-term employment growth and stability; by integrating into its day-to-day operations a concern for the physical and mental health, well-being and stress level of all employees; by developing their workforce's skills, competences, employability and careers in an entrepreneurial environment; and by promoting an effective life-work balance, a family friendly environment and equal opportunities regardless of gender, age, ethnicity, religion or sexual orientation.

Table 1. Social variables within Asset4 database

\begin{tabular}{ll}
\hline $\begin{array}{l}\text { Employment Quality } \\
\text { EQ1 }\end{array}$ & Competitive employee benefits policy \\
EQ2 & Long-term employment growth and stability policy \\
\hline $\begin{array}{l}\text { Health and Safety } \\
\text { HandS }\end{array}$ \\
\hline $\begin{array}{l}\text { Training and Development } \\
\text { TandD }\end{array}$ \\
\hline $\begin{array}{l}\text { Diversity } \\
\text { D1 }\end{array}$ \\
D2 & Training or career development policy \\
\hline
\end{tabular}

Source: Self compilation from Asset4 descriptions

Furthermore, we retrieved the environmental scores for the same companies for these years, and classified the companies into the major markets in which they are located. We divided the major markets into North America (NA), Europe (EUR), Asia/Pacific (ASIA) and the rest of the world as in Peiró-Signes and Segarra-Oña, 2013.

Initially, we applied the ANOVA test, comparing environmental scores in companies with and without social policies in order to detect mean differences across business functions (see Table 2).

Table 2. One-Way ANOVA results

\begin{tabular}{|c|c|c|c|c|}
\hline & & Mean & Scheffe's & F (sig.) \\
\hline \multirow[t]{2}{*}{ EQ1 } & NO & .365 & & $1602.03^{* * *}$ \\
\hline & YES & .572 & & \\
\hline \multirow[t]{2}{*}{ EQ2 } & NO & .410 & & $3615.07 * * *$ \\
\hline & YES & .726 & & \\
\hline \multirow[t]{2}{*}{ HandS } & NO & .234 & & $3355.13^{* * *}$ \\
\hline & YES & .568 & & \\
\hline \multirow[t]{2}{*}{ TandD } & NO & .257 & & $3466.45^{* * *}$ \\
\hline & YES & .577 & & \\
\hline \multirow[t]{2}{*}{$\mathrm{D} 1$} & NO & .387 & & $3407.29 * * *$ \\
\hline & YES & .670 & & \\
\hline \multirow[t]{2}{*}{ D2 } & NO & .291 & & $1870.16^{* * *}$ \\
\hline & YES & .552 & & \\
\hline \multirow[t]{4}{*}{ Location } & REST & .441 & (EUR. NA. ASIA) & $393.11 * * *$ \\
\hline & EUR & .624 & (REST. NA. ASIA) & \\
\hline & NA & .410 & (REST. EUR. ASIA) & \\
\hline & ASIA & .514 & (REST. EUR. NA) & \\
\hline
\end{tabular}

***Significant at $p<0.001$

Moreover, we applied the same one-way ANOVA tests according to major market area, followed by Scheffe's pairwise comparison procedure, to test for differences between individual pairs of groups in cases where one-way ANOVA results are statistically significant.

The ANOVA technique was conducted in order to assess differences across groups. Thus, we can confirm 
whether the mean of the environmental score is significantly different according to each firm's social policies. The ANOVA test highlighted significant differences between environmental scores in those companies that apply social policies over those that don't apply them. Furthermore, it indicated that all major market environmental scores were significantly different from each other.

Groups in parentheses indicate the group numbers from which this group was significantly different at the $p$ - 0.05 level according to the Scheffe's pairwise comparison procedure. F-statistics and associated $p$ values are derived from one-way ANOVAs.

However, although we can determine whether companies that promote social policies have higher environmental scores from the mean comparison analysis, we cannot determine whether that result is caused directly by the social policies.

For this purpose, we conducted a regression analysis study considering the entire sample and the former variables studied for this purpose. We undertook an analysis of residuals to check for the presence of outliers. Outliers were defined as the cases where standardized residuals are greater than 3.3 (corresponding to the .001 alpha level); we then excluded them from further analysis. To assess multivariate multicollinearity, we used the tolerance and variance inflation factor (VIF), that builds upon the regressing of each independent on all the others. All the independents met the general accepted threshold (tolerance higher than 0.2 and VIF lower than 4).

Initially, we took the environmental score to be dependent on social policies:

Environmental Score $=C+B_{1} E Q_{1}+b_{2} E Q_{2}+b_{3} H S+b_{4} T D+b_{5} D P_{1}+b_{6} D P_{2}+E$

In this model, $\beta_{1}$ will help us to determine whether a competitive employee benefit policy makes a difference to the environmental score. $\beta_{3}$, for example, will help us to determine whether there is a difference in the environmental score between companies that promote policies to improve employee health and safety over those companies that don't. A positive $\beta_{3}$ coefficient will indicate a higher score for the same value in other factors influencing the environmental scores.

In the model, we have considered the firms with no social policies as the omitted category; so all comparisons will be made in relationship to this group. Table 3 shows the results for the environmental score model.

In this case, we have to assess the significance of dummy variables as a set by using the $R^{2}$-change method and ignoring the individual t-tests produced by default for each dummy $\beta$ coefficient. Note that $R^{2}$-change and ANOVA F-change for the first set of variables are equal to $R^{2}$ and ANOVA $F$, respectively. The parameter $R^{2}$ - known as the coefficient of multiple determinations - indicates the percentage change in the dependent variable that can be explained by the independent variables in the model. Note that the relative predictive power of each specific variable is measured by the beta weights. The $\beta$ coefficient shows us how much more the dependent variable increases (or decreases if $\beta$ is negative) when each independent variable increases one unit; that is, in comparison to the omitted reference category.

Results indicate that when social policies are acting in an isolated way, environmental scores increase $\left(R^{2}=.404, p<0.001\right)$, which confirms that companies that promote social policies log higher scores in environmental scores $(H 1)$, as they are more developed culturally. Environmental scores are influenced mainly by EQ2 $\left(\beta_{2}=0.264\right), \mathrm{HS}\left(\beta_{3}=0.223\right), \mathrm{TD}\left(\beta_{3}=0.223\right)$ and $\mathrm{D} 1\left(\beta_{5}=0.231\right)$, when acting in an isolated way.

As environmental scores are affected by location, we had to create dummy variables to separate the effects of location from the environmental scores. Three dummy variables were modelled representing a company's major market location (EUR, NA and ASIA) so as to sort data into mutually exclusive locations and analyse their influence; these take a value of 0 or 1 depending on whether they are present or absent.

We added location terms to the model to incorporate the effect of social policies and location variables on the dependent variable (see Table 3 ). The new estimation model is as follows:

Environmental Score $=c+B_{1} E Q_{1}+B_{2} E Q_{2}+b_{3} H S+B_{4} T D+b_{5} D P_{1}+b_{6} D P_{2}+b_{7} E U R+B_{8} N A+b_{9} A S I A+E$

In the model, we have considered the firms outside of Europe, North America and Asia/Pacific with no social policies as the omitted category, so comparisons will be made in relationship to this group. 
Table 3. Regression results. Location effects on environmental scores

\begin{tabular}{lcc}
\hline & Model 1 & Model 2 \\
\hline Constant & $0.126(0)$ & $0.086(0)$ \\
\hline Employment quality Policy 1 & $0.018(0.027)$ & $0.042(0.063)$ \\
\hline Employment quality Policy 2 & $0.189(0.264)$ & $0.166(0.233)$ \\
\hline Healtht and Safety Policy & $0.174(0.223)$ & $0.171(0.22)$ \\
\hline Training and Development Policy & $0.132(0.179)$ & $0.103(0.14)$ \\
\hline DiversityPolicy1 & $0.151(0.231)$ & $0.138(0.211)$ \\
\hline DiversityPolicy2 & $0.016(0.02)$ & $0.055(0.071)$ \\
\hline EUR & & $0.076(0.105)$ \\
\hline NA & & $-0.041(-0.062)$ \\
\hline ASIA & & $0.09(0.124)$ \\
\hline ANOVA F & $1690^{* * *}$ & 1272 \\
\hline R2 & $.404^{* * *}$ & .434 \\
\hline F change & & $261^{* * *}$ \\
\hline R2 change & & $.030^{* * *}$ \\
\hline Bcoeffici*n
\end{tabular}

$\beta$ coefficients in braquets. ${ }^{* * *}$ Significant at $p<0.001$

An $F$-test of the significance of the location variables is the significance of the change of $R^{2}$ in the equation with the new terms and the equation without them.

The new model was considered significantly $(\operatorname{sig}(F)<.05)$ better than would be expected by chance; therefore, we can reject the null hypothesis of no linear relationship between each of these variables to the independent variables.

\section{Results}

The results indicate that companies in Europe and Asia have higher environmental scores than those located in the rest of the world $\left(\beta_{7}=0.105 ; \beta_{9}=0.124\right)$ when the same type of social policies is applied. On the contrary, companies in North America achieve significantly lower scores $\left(\beta_{8}=-0.062\right)$ than those in the omitted category. These results are in accordance with previous findings (Peiró-Signes and Segarra-Oña, 2013).

Table 4. Regression results by location

\begin{tabular}{lcccc}
\hline & Europe & North America & Asia & Rest of the world \\
\hline Constant & & & & \\
\hline Employment quality Policy 1 & 0.159 & 0.102 & -0.047 & 0.062 \\
\hline Employment quality Policy 2 & 0.232 & 0.241 & 0.204 & 0.253 \\
\hline Healtht and Safety Policy & 0.212 & 0.225 & 0.2 & 0.29 \\
\hline Training and Development Policy & 0.103 & 0.174 & 0.095 & 0.131 \\
\hline DiversityPolicy1 & 0.141 & 0.203 & 0.353 & 0.135 \\
\hline DiversityPolicy2 & 0.107 & 0.024 & 0.095 & 0.043 \\
\hline Anova F & $404.622^{* * *}$ & $527.166^{* * *}$ & $599.816^{* * *}$ & $163.075^{* * *}$ \\
\hline R2 & $0.383^{* * *}$ & $0.356^{* * *}$ & $0.477^{* * *}$ & $0.422^{* * *}$ \\
\hline
\end{tabular}

Standardized $\beta$ coefficients $* * *$ Significant at $\mathrm{p}<0.001$

However, we wanted to test the joint effect of social policies and location variables on a dependent variable over and above their separate effects; that is, we want to confirm that location acts as a moderator.

To test this, a typical approach is to add interaction terms to the model. However, cross-product interaction terms may be highly correlated (multicollinear) with the corresponding simple independent variables in the regression equation, creating problems when assessing the relative importance of main 
effects and interaction effects. To avoid multicollinearity, an alternative to the cross-product approach is to run separate regressions for each level of the interacting variables ${ }^{8}$. Moreover, this method will help us to compare the results between locations more effectively.

Therefore, we ran separate regressions for each location (see Table 4).

For the analysis of the differences between each major market, we calculated the difference between the standardized coefficients of each sample (see Table 5).

Table 5. Comparison of coefficients between locations

\begin{tabular}{|c|c|c|c|c|c|c|}
\hline$\beta \mathbf{i}-\beta \mathbf{j}$ & $\begin{array}{c}\text { Europe- North } \\
\text { America }\end{array}$ & Europe-Asia & $\begin{array}{c}\text { Europe- } \\
\text { Rest }\end{array}$ & $\begin{array}{c}\text { North } \\
\text { America-Asia }\end{array}$ & $\begin{array}{c}\text { North } \\
\text { America-Rest }\end{array}$ & Asia-Rest \\
\hline $\begin{array}{l}\text { Employment quality } \\
\text { Policy } 1\end{array}$ & $\begin{array}{c}0.057 \\
(304)^{* * *}\end{array}$ & $\begin{array}{c}0.206 \\
(999)^{* * *}\end{array}$ & $\begin{array}{c}0.097 \\
(265)^{* * *}\end{array}$ & $\begin{array}{c}0.149 \\
(861)^{* * *}\end{array}$ & $\begin{array}{c}0.04 \\
(130)^{* * *}\end{array}$ & $\begin{array}{c}-0.109 \\
(-326)^{* * *}\end{array}$ \\
\hline $\begin{array}{l}\text { Employment quality } \\
\text { Policy } 2\end{array}$ & $\begin{array}{c}-0.009 \\
(-52)^{* * *}\end{array}$ & $\begin{array}{c}0.027 \\
(134)^{* * *}\end{array}$ & $\begin{array}{c}-0.021 \\
(-65)^{* * *}\end{array}$ & $\begin{array}{c}0.037 \\
(188)^{* * *}\end{array}$ & $\begin{array}{c}-0.012 \\
(-38)^{* * *}\end{array}$ & $\begin{array}{c}-0.049 \\
(-134)^{* * *}\end{array}$ \\
\hline $\begin{array}{l}\text { Healtht and Safety } \\
\text { Policy }\end{array}$ & $\begin{array}{c}-0.013 \\
(-54)^{* * *}\end{array}$ & $\begin{array}{c}0.012 \\
(42)^{* * *}\end{array}$ & $\begin{array}{c}-0.078 \\
(-166)^{* * *}\end{array}$ & $\begin{array}{c}0.025 \\
(123)^{* * *}\end{array}$ & $\begin{array}{c}-0.065 \\
(-196)^{* * *}\end{array}$ & $\begin{array}{c}-0.09 \\
(-230)^{* * *}\end{array}$ \\
\hline $\begin{array}{l}\text { Training and } \\
\text { Development Policy }\end{array}$ & $\begin{array}{c}-0.071 \\
(-289)^{* * *}\end{array}$ & $\begin{array}{c}0.008 \\
(28)^{* * *}\end{array}$ & $\begin{array}{c}-0.028 \\
(-55)^{* * *}\end{array}$ & $\begin{array}{c}0.079 \\
(427)^{* * *}\end{array}$ & $\begin{array}{c}0.043 \\
(139)^{* * *}\end{array}$ & $\begin{array}{c}-0.036 \\
(-96)^{* * *}\end{array}$ \\
\hline DiversityPolicy1 & $\begin{array}{c}-0.062 \\
(-390)^{* * *}\end{array}$ & $\begin{array}{c}-0.212 \\
(-1070)^{* * *}\end{array}$ & $\begin{array}{c}0.006 \\
(18)^{* * *}\end{array}$ & $\begin{array}{c}-0.149 \\
(-863)^{* * *} \\
\end{array}$ & $\begin{array}{c}0.069 \\
(234)^{* * *}\end{array}$ & $\begin{array}{c}0.218 \\
(603)^{* * *} \\
\end{array}$ \\
\hline DiversityPolicy2 & $\begin{array}{c}0.083 \\
(326)^{* * *}\end{array}$ & $\begin{array}{c}0.012 \\
(44)^{* * *}\end{array}$ & $\begin{array}{c}0.064 \\
(138)^{* * *}\end{array}$ & $\begin{array}{c}-0.071 \\
(-316)^{* * *}\end{array}$ & $\begin{array}{c}-0.018 \\
(-48)^{* * *}\end{array}$ & $\begin{array}{c}0.052 \\
(133)^{* * *}\end{array}$ \\
\hline
\end{tabular}

t significance test in brackets. ${ }^{* * *}$ Significant at $p<0.001$

To calculate the corresponding t-value, the following expression was used:

$$
t=\frac{\beta_{i}-\beta_{j}}{\sqrt{\frac{(m-1) \cdot S E_{i}^{2}+(n-1) \cdot S E_{j}^{2}}{m+n-2}} \cdot \sqrt{\frac{1}{m}+\frac{1}{n}}}
$$

where $\beta_{i}$ and $\beta_{j}$ represent the $\beta$ values for each pair of major market areas; $S E_{i}$ and $S E_{j}$ are the standard errors; and $m$ and $n$ are the number of data points for $i$ and $j$ areas, respectively. Table 5 shows the results of this analysis.

\section{Discussion}

Location analysis indicated that long-term employment growth and stability (EQ2) and health and safety (HS) policies have an important impact on the environmental scores in all the major markets. Those findings are aligned with the Environmental Kuznets Curve (EKC)-statement (Kuznets, 1995), which states that environmental degradation is created during the first stages of the economic development while the process of economic growth will eventually eliminate any environmental problems as regulations and environmental policies become more specific.

Training and development policies have a greater impact in North America than in the rest of the world, and little impact in Asia, which would support the theory, as Asia is in a lower development stage than North America, therefore their main objective, is growing. In the same direction, we found that, competitive employee benefits policies (EQ1) have a moderate impact in Europe and North America, almost no impact in the rest of the world, and negative impact in Asia.

Finally, work-life balance policies (D1) have the biggest impact in Asia, while diversity and equal opportunity policies have the lowest impact among the evaluated policies. Indeed, these results confirm the need to balance social aspects of day-to day life and work conditions, especially for those who mainly take care of (women) if we can foster environmental awareness and move from an initial stage of industrial growing to a more enhanced level of economic development. 
A t-test revealed that beta values in each area are significantly different from each other, thus confirming our second hypothesis that stated that the influence on the environmental score of companies varies depending on where companies are located.

To sum up, this discussion about environmental scores highlights that this indicator is affected significantly by social policies, and that location acts as a moderating factor.

\section{Conclusion}

The objective of this study was to analyse environmental scores in companies adopting social policies. We found that companies that promoted social policies evidence a difference in their environmental scores over those that did not. Moreover, an analysis of the sample confirmed location as a differentiating factor. Companies located in Europe or Asia achieved generally higher scores than those located in North America and the rest of the world. These results are partly aligned with previous analysis that defined income per capital as a proxy for environmental pollution (Hettige et al., 2000), although one could have expected North America to obtain higher environmental scores.

It is not surprising that the ANOVA revealed significant differences between the major markets, as environmental regulations are quite different across the globe.

We proved an interaction between employment quality, health and safety, training and development and diversity policies and environmental scores. In order to validate our first hypothesis - which stated that companies' environmental scores are affected by social policies implementation -a complementary analysis using dummy variables to isolate the effects of each policy in the first analysis was conducted. Thus, it was investigated the individual effects of social policies and location on environmental performance. The results showed significant changes in environmental scores; therefore, the data supported the assumption that better environmental scores were directly caused by the promotion of social policies. We can conclude that the promotion of social policies positively affects the environmental orientation of the firm; that is, a company's management commitment and effectiveness towards providing high-quality employment benefits and job conditions, a healthy and safe workplace, education and equal opportunities in its workforce affects the environmental performance of companies.

We argue that companies with management commitment and loyal employees are culturally more developed, and it will be more sensible for them to promote environmental aspects in their structures and processes. Moreover, a regression analysis revealed that location was a significant predictor for environmental scores $\left(R^{2}\right.$-change $\left.=0.03, p<0.001\right)$. The differences between the locations are evident, which could be due to the different environmental regulations companies face in each region (Burciu et al., 2010; Šauer et al., 2012; Beare et al., 2014).

Our cross study of the relationship between social policies and location revealed some interesting insights. Models for each location highlighted that the impact of each social policy on the environmental scores changes according to company location, confirming the moderator effect of location on environmental scores. These results confirm our second hypothesis (The influence on the environmental score of companies varies depending on where companies are located).

The differences between firms that promote social policies and those that don't are evident. We confirmed the role of location, demonstrating that being located in major markets where strong environmental regulations apply implies higher environmental orientation regardless of the social policies applied. Finally, we have determined how location moderates the relative impact of each policy on the environmental performance.

The limitations of this research include the available sample and data. Only large companies have resources to issue corporate social responsibility reports or be included in the ESG ratings, thus limiting our conclusions. Future research should focus on the use of different methodologies, with more complex (i.e. a larger variety of organizational factors) and larger databases, as well as panel studies. An in-depth 
qualitative case study will be necessary to obtain further information on why diversity policies perform this way.

\section{Acknowledgment}

The authors would like to thank the Valencian Government for its support through the research project (GV/2015/003) and the Universitat Politecnica de Valencia for the ADSIDEO 2014 Grants led by prof. Segarra (Centre for Cooperation and Development)..

\section{References}

Alonso-Almeida M., Llach J. and Marimon F. (2014), A closer look at the 'Global Reporting Initiative'sustainability reporting as a tool to implement environmental and social policies: A worldwide sector analysis, Corporate Social Responsibility and Environmental Management, 21(6), 318-335.

Beare D., Buslovich R. and Searcy C. (2014), Linkages between corporate sustainability reporting and public policy, Corporate Social Responsibility and Environmental Management, 21(6), 336-350.

Burciu A., Bostan I., Condrea P. and Grosu, V. (2010), Financing the environmental policies in the communitarian space, Environmental Engineering and Management Journal, 9 (9), 1179-1185.

Charisiou N.D. and Goula M.A. (2014), Attitudes of Greek university students towards energy and the environment, Global NEST Journal, 16(5), 856-865.

Cheng B., loannou I. and Serafeim G. (2014), Corporate social responsibility and access to finance, Strategic Management Journal, 35(1), 1-23.

Collison D.J., Cobb G., Power D.M. and Stevenson L.A. (2008), The financial performance of the FTSE4Good indices, Corporate Social Responsibility and Environmental Management, 15(1), 14-28.

Dankelman I. and Davidson J. (2013), Women and the Environment in the Third World: Alliance for the Future. Earthscan, London.

Dobler M., Lajili K. and Zéghal D. (2014), Environmental performance, environmental risk and risk management, Business Strategy and the Environment, 23(1), 1-17.

Eccles R.G., loannou I. and Serafeim G. (2011), The impact of a corporate culture of sustainability on corporate behavior and performance, Working Paper, 12-035, Harvard Business Review.

Eiadat Y., Kelly A., Roche F. and Eyadat H. (2008), Green and competitive? An empirical test of the mediating role of environmental innovation strategy, Journal of World Business, 43(2), 131-145.

Filbeck G., Gorman R. and Zhao X. (2009), The "Best Corporate Citizens": Are They Good for Their Shareholders?, Financial Review, 44(2), 239-262.

Franck K.A. (2002), Women and environment pp. 347-362.in Handbook of environmental psychology, Wiley, Bechtel R.B. and Churchman A. Eds.

Garau G., Mandras G. and Schirru L. (2011), A statistical information system supporting environmental policies, Environmental Engineering and Management Journal, 10(12), 1903-1910.

Griffiths A. (2004), Corporate sustainability and innovation, Innovation: management, policy and practice, 6(23), 6-14.

Hall J. and Vredenburg H. (2004), Sustainable development innovation and competitive advantage: implications for business, policy and management education, Innovation: management, policy and practice, 6(2), 129-140.

Hettige H., Mani M. and Wheeler D. (2000), Industrial pollution in economic development: the environmental Kuznets curve revisited, Journal of Development Economics, 62 (2), 445-476.

Hong H. and Kacperczyk M. (2009), The price of sin: The effects of social norms on markets, Journal of Financial Economics, 93(1), 15-36.

Humm M. (1995), The dictionary of feminist theory. Columbus, OH: Ohio State University Press.

Ioannou I. and Serafeim G. (2010), What Drives Corporate Social Performance?: International Evidence from Social, Environmental and Governance Sources. Cambridge, Harvard Business School. 
Kemp R., Parto S. and Gibson R.B. (2005), Governance for sustainable development: moving from theory to practice, International Journal of Sustainable Development, 8(1), 12-30.

Knoll M.S. (2002), Ethical screening in modern financial markets: the conflicting claims underlying socially responsible investment, The Business Lawyer, 681-726.

Kolk A. and Pinkse J. (2010), The integration of corporate governance in corporate social responsibility disclosures, Corporate Social Responsibility and Environmental Management, 17(1), 15-26.

Kuznets S. (1995), Economic growth and income inequality, American Economic Review, 45, 1-28

Meissner R. (2015), The Relevance of Social Theory in the Practice of Environmental Management, Science and engineering ethics, 22, 1345-1360.

Merchant C. (1981), Earthcare: Women and the environment, Environment: Science and Policy for Sustainable Development, 23(5), 6-40.

Mio C. and Venturelli A. (2013), Non-financial Information about Sustainable Development and Environmental Policy in the Annual Reports of Listed Companies: Evidence from Italy and the UK, Corporate Social Responsibility and Environmental Management, 20(6), 340-358.

Peiró-Signes A., Segarra-Oña M., Mondéjar-Jiménez J. and Vargas-Vargas M. (2012), Influence of the environmental, social and corporate governance ratings on the economic performance of companies: An overview, International Journal of Environmental Research, 7(1), 105-112.

Peiró-Signes A. and Segarra-Oña M. (2013), Trends in ESG Practices: Differences and Similarities across Major Developed Markets. In Sustainability Appraisal: Quantitative Methods and Mathematical Techniques for Environmental Performance Evaluation, pp. 125-140, Springer Berlin Heidelberg.

Perron G.M., Côté R.P. and Duffy J.F. (2006), Improving environmental awareness training in business, Journal of Cleaner Production, 14(6), 551-562.

Persada S., Lin S., Nadlifatin R. and Razif M. (2015), Investigating the citizens' intention level in environmental impact assessment participation through an extended theory of planned behavior model, Global Nest Journal, 17, 847-857

Porter M.E. and Van der Linde C. (1995), Green and competitive: ending the stalemate, Harvard Business Review, Reprint 95507, 120-134.

Porter M.E. and Van der Linde C. (1995), Towards a new conception of the environment-competitiveness relationship, The journal of economic perspectives, 9(4), 97-118.

Šauer P., Kreuz J., Hadrabová A. and Dvořák A. (2012), Assessment of environmental policy implementation: Two case studies from the Czech Republic, Polish Journal of Environmental Studies, 21(5), 1383-1391.

Schneekloth L.H. (1994), Partial Utopian Visions, In Women and the environment (pp. 281-306). Springer US.

Segarra-Oña M., Peiró-Signes A. and Mondejar-Jimenez J.A. (2014), Are companies environmental scores affected by diversity of policies and women's presence? An overview of environmental conditionants, Environmental Engineering and Management Journal, 13(10), 2425-2430.

Sugita M. and Takahashi T. (2015), Influence of corporate culture on environmental management performance: an empirical study of japanese firms, Corporate Social Responsibility and Environmental Management, 22(3), 182-192.

Sullivan R. (2002), Being sustainable... be specific [environmental management]. Engineering Management Journal, 12(5), 220-225.

Stromquist N.P. (Ed.), (2014), Women in the Third World: An encyclopedia of contemporary Issues, Routledge. 